UDC 349.3

DOI 10.31733/2078-3566-2019-5-164-167

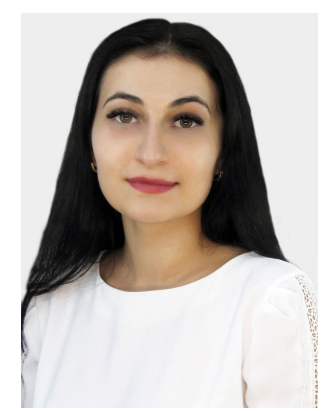

Liusia MOZHECHUK ${ }^{\odot}$

Post-graduate

(Dnipropetrovsk State

University of Internal Affairs)

\title{
THE RIGHT TO A PENSION PROVISION FOR EDUCATION EMPLOYEES OF UKRAINE UNDER PENSION REFORM CONDITIONS
}

Люся МожечУК. ПРАВО НА ПЕНСІЙНЕ ЗАБЕЗПЕЧЕННЯ ПРАЦІВНИКІВ ОСВІТИ УКРАЇНИ В УМОВАХ ПЕНСІЙНОЇ РЕФОРМИ. РозкриТо питання реалізації громадянами України конституційного права на пенсійне забезпечення. Зокрема, увагу зосереджено на пенсійному забезпеченні працівників освіти. Проаналізовано етапи пенсійної реформи, охарактеризовано зміни та нововведення. Розкрито зміст поняття «пенсія за вислугу років», визначено умови іiі призначення. Здійснено аналіз судової практики в частині пенсійного забезпечення працівників освіти України.

Аналізуючи сьогоднішній стан пенсійної системи України, виявлено окремі вади пенсійної реформи, зокрема ії екстенсивний розвиток, не всі законодавчі норми різних законів узгоджуються між собою, або виявляються не продуманими механізми реалізації тих, чи інших «нововведень». Про що свідчить рішення Конституційного Суду України від 04 червня 2019 року № 2-р/2019 щодо відповідності Конституції України (конституційності) окремих положень Закону України «Про пенсійне забезпечення». Цим рішенням Конституційний Суд України визнав такими, що не відповідають Конституції України (є неконституційними), деякі положення Закону України «Про пенсійне забезпечення» від 05.11.1991.

Зазначено, що пенсійні системи є невід’ємною частиною складовою національних систем соціального забезпечення - основою інструменту державної політики у сфері надання соціальної підтримки та захисту населення. Пенсійна реформа в Україні внесла багато новацій, змін до законодавства, проте, деякі 3 них, як показує судова практика, суперечать нормам Конституції України, порушуючи при цьому сутність права на соціальний захист, зокрема, щодо пенсійного забезпечення працівників освіти, а саме можливості виходу на пенсію за вислугу років. Пенсійне забезпечення за вислугу років для науково-педагогічних працівників є вкрай необхідним, адже, педагогічна діяльність часто призводить до втрати професійної працездатності.

Ключові слова: право на сочіальний захист, пенсійне забезпечення, пенсійне реформування, пенсійна система, пенсія за вислугу років, страховий стаж, освітянська діяльність.

Problem statement. Among the vital socio-economic and political problems that dominate the domestic information space, a special place is given to pension provision [1, p. 4]. Citizens' pension provision is one of the major components of a socially oriented state. The existence of guaranteed Ukrainian pension rights for Ukrainian citizens should be considered as a realization of a certain level of civilization of the state's development and its humane maturity. The constitution of Ukraine contains imperative norms that give every citizen a guaranteed social security. The Basic Law of the country not only confirms the social character, but establishes the primacy of the responsibility of the legitimate authorities in matters of pension provision of citizens [2, p. 7]. The problem of realization of pension rights by the citizens in Ukraine is still acute and urgent as it has been throughout the period of formation of the national pension system and permanent reform of the legislation in this field. This problem has repeatedly generated discussions of scientists in the context of possible improvement of this procedure for the benefit of citizens or, conversely, of the state.

Analysis of publications that started solving this problem. The legal aspects of citizens' realization of the right to retirement pension were, to one extent or another, the object of study of such contemporary Ukrainian scientists as N.B. Bolotina, I.P. Bomberger, V.Ya. Burak, O.I. Kul'chic'ka, S.V. Vishnovec'ka, T.O. Didkovs'ka, M.M. Klempars'ky, N.P. Korobenko, L.M. Knyaz'kov, T.V. Kravchuk, I.Yu. Mikhaylova, S.M. Prilipko, O.M. Yaroshenko, N.M. Khutoryan, Ya.V. Simutina, M.P. Stadnik, A.A. Shirant, O.V. Tyshchenko, M.M. Shumilo and others. At the same time, the pension reform conducted in Ukraine introduced sub-

(C) Mozhechuk L., 2019

ORCID iD: https://orcid.org/0000-0002-8368-7447

luca.moshetschuk@ukr.net 
stantially new legal conditions for citizens to exercise their pension rights [12, p. 101-102]. Particularly noteworthy is the issue of pension provision for educators in Ukraine.

The article's objective is to analyze the issues of pension provision for educatiors in Ukraine as a result of pension reform.

Basic content. The pension system, by its structure and content, is a complex set of institutions, relationships and mechanisms through which pension funds are formed and appropriate conditions are created for the provision of pensions to the incapacitated population. An integral part of the pension system is pension provision [3, p. 24]. Despite the fact that a number of important changes for the further development of the pension system have been implemented in the country today, the pension system of Ukraine is in a serious crisis. The crisis is manifested in the low level of pensions, the lack of proper differentiation of pensions depending on the length of service, the long-term deficit of the Pension Fund budget, and as a consequence, the strengthening of the dependence of the pension system on transfers from the state budget [2, p. 7]. Under the current conditions of socio-economic development, pension provision is one of the main social security institutions designed to protect citizens from poverty after the retirement age, raise the standard of living of pensioners, establish the dependence of pensions on the size of earnings and seniority, ensure the financial stability of the pension system. [10, p.13].Pension provision is a collection of pension entitlements for persons who are entitled to it by law or contractual relationship. The first way is a distributive system whereby the provision of pensions to the citizens is not related to the contributions paid in advance and is not conditioned by the loss of earnings; the second way is cumulative, by which the pension contributions are accumulated [7, p. 7].

The structure of the national pension system is defined in the Law of Ukraine "On compulsory pension insurance". According to article 2 of the Law of Ukraine "On compulsory pension insurance" the pension system in Ukraine consists of three levels: a solidarity system of compulsory state pension insurance; compulsory system of compulsory state pension insurance; the system of non-state pension provision [8].

The solidarity system is the basis of pension provision of Ukraine, which aims to provide a minimum pension, which is a guaranteed pension of every citizen after retirement. Financing of these payments is made by compulsory deductions from the salaries of citizens to the Pension Fund of Ukraine [9, pp. 5-6].

On October 11, 2017, the Law of Ukraine "On Amendments to Certain Legislative Acts of Ukraine on Raising Pensions" came into force, which defined the priority directions of reforming the pension system of Ukraine. In particular, the purpose of the reform is to 1) modernize pensions, that is, adjust them according to the increase in the average wage from which contributions are paid; 2) establish requirements for the amount of required length of service; 3 ) abolish the special conditions for retirement and taxation of pensions [4, p. 1225]. The law provides for the introduction of an automatic provision for annual indexation (recalculation) of pensions to protect against inflation, taking into account the financial capacity of the solidarity system, but not less than 50\% increase in average wages over three years and $50 \%$ of the consumer price index. In addition, the special legal act abolishes special pensions for civil servants, judges, scientists and others categories [5]. Particular attention should be paid to the pension provision of educators, in particular, the possibility of retirement for years of service.

Analyzing the norms of the current legislation of Ukraine, which directly regulate the legal relations in the sphere of pension insurance; it is possible to state that there is no definition at the legislative level of the concept of "pension for years of service". Article 51 of the Law of Ukraine "On Pension Insurance" states that pensions for years of service are for certain categories of citizens employed in the work, the performance of which leads to loss of professional capacity or age, which entitles to retirement by age [13]. Scientists propose the following definitions of this concept. T.P. Kolesnik-Omelchenko defines years of service pension as a monthly monetary payment from the Pension Fund of Ukraine to be assigned to teaching staff in the amount correlated with past earnings, with a length of service of at least 25 years in positions established by law, regardless of age [11, p. 9]. I.M. Sirota notes that years of service is a special kind of special experience of certain categories of workers, which provides preferential retirement benefits in connection with the loss of a professional pension working capacity and retirement before the age of retirement, which entitles to retirement by age $[15, \mathrm{p} .86]$.

Thus, a lifetime service pension is a monthly cash benefit received by a circle of persons determined by a special legal act in the presence of a special length of service.

Unlike other types of pensions, pensions for years of service are to provide a source of 
livelihood, encourage early retirement due to the threat of premature occupational aging and attract labor in certain areas of the national economy. The calculation of age pension on a general basis is carried out according to the formula, the main components of which are the salary (income) of the insured person and the coefficient of insurance length of service, which has rather complex accounting principles [14, p. 12-13].

Thus, analyzing the current state of the pension system of Ukraine, we can talk about some of the disadvantages of the pension reform, including its extensive development, not all legislative provisions of different laws are consistent with each other or the mechanisms of implementation of these or other "innovations" are not considered. The decision of the Constitutional Court of Ukraine of June 4, 2019 No. 2-r / 2019 on compliance of the Constitution of Ukraine (constitutionality) with certain provisions of the Law of Ukraine "On Pension Provision" can be considered as evidence to this. By this decision, the Constitutional Court of Ukraine found some provisions of the Law of Ukraine "On Pension Provision" of 17.11.1991 No. 1788-XII to be inconsistent with the Constitution of Ukraine (which are unconstitutional). The Constitutional Court of Ukraine notes: that changes in the pension sector must be sufficiently substantiated, carried out gradually, carefully and in advance in a reasoned way, based on objective criteria, proportionate to the purpose of changing legal regulation, ensuring a fair balance between the general interests of society and the duty to protect human rights, without violating the essence of the right to social protection [6].

The Decision states that the Law of Ukraine on Pension Insurance establishes as an additional condition for granting a retirement pension of certain age to certain categories of workers, in particular reaching the age of 55 for education, health and social security workers. Article 51 of Law No. 1788 provides retirement pensions for certain categories of citizens employed in work, the performance of which leads to the loss of professional capacity or age, which entitles them to retirement by age. These are jobs that have a direct impact on the health of the employee and may lead to a loss of professional capacity (ability to work in the occupation) before the age of entitlement to retirement age [6]. Thus, the loss of professional capacity or fitness is not related to reaching a certain age, so it cannot be a condition for a retirement pension. The Constitutional Court of Ukraine proceeds from the fact that the establishment as an additional condition for the appointment of a retirement pension of 55 years of age for the persons mentioned in clauses "e", "w" of Article 55 of the Law of Ukraine on Pension Security, negates the essence of the right to social security and protection, it does not comply with the constitutional principles of the welfare state and is contrary to the provisions of Articles 1, 3, Part 3 of Article 22, Article 46 of the Basic Law of Ukraine [6].

The Constitutional Court also states that the legislator, by equalizing retirement age for men and women engaged in relevant work, which is associated with harmful effects on health and leads to loss of professional capacity or fitness to the age that gives the right to retirement by age, abolished special guarantees for the protection of women's work and health, and set special conditions for obtaining the right to retirement pension for years [6].

Conclusions. In the context of social development, it is important to note that pension systems are an integral part of national social security systems - the basis of public policy instruments in the field of social support and protection of the population [2, p. 28]. The pension reform in Ukraine has introduced a lot of innovations, changes to the legislation, however, some of them, according to the case law, contradict the norms of the Constitution of Ukraine, thus violating the essence of the right to social protection, in particular, regarding pension provision for educators, namely opportunities of retirement for years of service. Lifetime retirement benefits for teaching staff are essential, as pedagogical activities often result in loss of professional capacity.

\section{References}

1. Буряченко О. Є. Пенсійна система в Україні: історія становлення і теоретичні засади розвитку на сучасному етапі національного державотворення : дис.... канд. наук $з$ держ. упр. : 25.00.01 / Одес. регіон. ін-т держ. упр. Нац. акад. держ. упр. при Президентові України. Одеса, $2017,252 \mathrm{c}$

2. Фінансові, соціальні та правові аспекти пенсійної реформи в Україні. URL : http://razumkov.org.ua/uploads/article/2017-PENSII.pdf.

3. Єлісєєва Л. В., Примачук Н. С. Пенсійна система країни: виклики та перспективи. Економічний аналіз. 2016. Том 23. № 1. С. 23-27.

4. Ставерська Т. О., Шевчук І. Л. Етапи пенсійної реформи в Україні. Економіка $i$ суспільство. № 13. 2017. С. 1221-1228.

5. URL : https:/www.unian.ua/economics/finance/2180336-nabrav-chinnosti-zakon-propensiynu-reformu-scho-chekae-ukrajintsiv.html.

6. URL : http://osvitapoltava.gov.ua/профіспілкові-новини.

7. Шалієвська Л. І. Пенсійне забезпечення в системі економічної безпеки держави: 
автореф. дис. ... канд. екон. наук : 21.04.01 / Львів. держ. ун-т внутр. справ. Львів, 2019. 23 с.

8. Про загальнообов'язкове пенсійне страхування: Закон України від 09 липня 2003 № 1058-IV. URL : http://zakon5.rada.gov.ua/laws/show/1058-15.

9. Александрова Г. М., Кондакова Ю. Б. Сучасний стан пенсійної системи України. Молодий вчений. № 6. 2016. С. 4-8.

10. Міндова О. I. Трансформація пенсійної системи в умовах євроінтеграції України: автореф. дис. ... канд. екон. наук : 08.00.08/ ПВНЗ "Свропейський університет". Київ, 2017, 23 с.

11. Колєснік-Омельченко Т. В. Правове регулювання пенсійного забезпечення за вислугу років педагогічних працівників: автор. дис.... канд. юрид. наук : 12.00 .05 / Східноукр. нац. ун-т ім. В. Даля. Луганськ, 2009, 23 с.

12. Пенсійне забезпечення в Україні та Білорусі: історія становлення і перспективи розвитку: монографія / за ред. М. Шумила, І. Комоцької. Київ : Ніка-Центр, 2018. 516 с.

13. Про пенсійне забезпечення: Закон України від 05.11.1991 № 1788-XI. URL : https://zakon.rada.gov.ua/laws/show/1788-12.

14. Колотік А. С. Правове регулювання спеціального пенсійного забезпечення в Україні: автореф. дис. ... канд. юрид. наук : 12.00.05 / Нац. ун-т "Юрид. акад. України ім. Ярослава Мудрого". Харків, 2011, 20 с.

15. Сирота I. М. Право пенсійного забезпечення в Україні : курс лекцій. Київ : Юрінком Інтер, 1998, 288 c.

Received to editorial office 10.12.2019

1. Buryachenko, O. Ye. (2017) Pensiyna systema v Ukrayini: istoriya stanovlennya i teoretychni zasady rozvytku na suchasnomu etapi natsional'noho derzhavotvorennya [Pension system in Ukraine: history of formation and theoretical foundations of development at the present stage of national state formation]: dys.... kand. nauk z derzh. upr. : 25.00.01 / Odes. rehion. in-t derzh. upr. Nats. akad. derzh. upr. pry Prezydentovi Ukrayiny. Odesa, 252 s. [in Ukr.]

2. Finansovi, sotsial'ni ta pravovi aspekty pensiynoyi reformy v Ukrayini [Financial, social and legal aspects of pension reform in Ukraine]. URL : http://razumkov.org.ua/uploads/article/2017PENSII.pdf. [in Ukr.]

3. Yelisyeyeva, L. V., Prymachuk, N. S. (2016) Pensiyna systema krayiny: vyklyky ta perspektyvy [The Pension System of the Country: Challenges and Prospects]. Ekonomichnyy analiz. Tom 23. № 1. S. 23-27. [in Ukr.]

4. Stavers'ka, T. O., Shevchuk, I. L. (2017) Etapy pensiynoyi reformy v Ukrayini [Stages of pension reform in Ukraine]. Ekonomika i suspil'stvo. № 13. S. 1221-1228. [in Ukr.]

5. URL : https://www.unian.ua/economics/finance/2180336-nabrav-chinnosti-zakon-propensiynu-reformu-scho-chekae-ukrajintsiv.html. [in Ukr.]

6. URL : http://osvitapoltava.gov.ua/profispilkovi-novyny. [in Ukr.]

7. Shaliyevs'ka, L. I. (2019) Pensiyne zabezpechennya v systemi ekonomichnoyi bezpeky derzhavy [Pension provision in the system of economic security of the state]: avtoref. dys. ... kand. ekon. nauk : 21.04.01 / L'viv. derzh. un-t vnutr. sprav. L'viv, 23 s. [in Ukr.]

8. Pro zahal'noobov"yazkove pensiyne strakhuvannya [On compulsory pension insurance]: Zakon Ukrayiny vid 09 lypnya 2003 № 1058-IV. URL : http://zakon5.rada.gov.ua/laws/show/1058-15. [in Ukr.]

9. Aleksandrova, H. M., Kondakova, Yu. B. (2016) Suchasnyy stan pensiynoyi systemy Ukrayiny [The current state of the pension system of Ukraine]. Molodyy vchenyy. № 6. S. 4-8. [in Ukr.]

10. Mindova, O. I. (2017) Transformatsiya pensiynoyi systemy v umovakh yevrointehratsiyi Ukrayiny [Transformation of the Pension System in the Conditions of European Integration of Ukraine]: avtoref. dys. ... kand. ekon. nauk : 08.00.08/ PVNZ "Yevropeys'kyy universytet". Kyyiv, , 23 s. [in Ukr.]

11. Kolyesnik-Omel'chenko, T. V. (2009) Pravove rehulyuvannya pensiynoho zabezpechennya za vysluhu rokiv pedahohichnykh pratsivnykiv [Legal regulation of pension provision for years of teaching staff]: avtor. dys.... kand. yuryd. nauk : 12.00.05 / Skhidnoukr. nats. un-t im. V. Dalya. Luhans'k, 23 s. [in Ukr.]

12. Pensiyne zabezpechennya v Ukrayini ta Bilorusi: istoriya stanovlennya i perspektyvy rozvytku [Pensions in Ukraine and Belarus: History of Formation and Prospects for Development]: monohrafiya / za red. M. Shumyla, I. Komots'koyi. Kyiv : Nika-Tsentr, 2018. 516 s. [in Ukr.]

13. Pro pensiyne zabezpechennya [On pension provision]: Zakon Ukrayiny vid 05.11.1991 № 1788-XI. URL : https://zakon.rada.gov.ua/laws/show/1788-12. [in Ukr.]

14. Kolotik, A. S. (2011) Pravove rehulyuvannya spetsial'noho pensiynoho zabezpechennya v Ukrayini [Legal regulation of special pension insurance in Ukraine]: avtoref. dys. ... kand. yuryd. nauk : 12.00.05 / Nats. un-t "Yuryd. akad. Ukrayiny im. Yaroslava Mudroho". Kharkiv, 20 s. [in Ukr.]

15. Syrota, I. M. (1998) Pravo pensiynoho zabezpechennya v Ukrayini [Pension law in Ukraine]: kurs lektsiy. Kyiv : Yurinkom Inter, 288 s. [in Ukr.]

\section{Summary}

The article deals with the issue of realization of the constitutional right to pension provision by the citizens of Ukraine. In particular, the focus is on pension provision for educators. The stages of pension reform are analyzed, changes and innovations are characterized. The content of the concept of "retirement pension for years" is revealed, the terms of its appointment are determined. The court practice in the part of pension provision of educators of Ukraine is analyzed in this article.

Keywords: the right to social protection, pension provision, pension reform, pension system, retirement pension, insurance experience, educational activities. 